\title{
Rola innowacji w funkcjonowaniu przedsiębiorstw przemysłowych
}

W literaturze zarówno polskiej jak i zagranicznej możemy spotkać wiele różnych definicji innowacji. Biorąc pod uwagę literaturę zagraniczną, najbardziej lapidarną definicję podaje J.A. Allen: „innowacją jest wprowadzenie do szerokiego użytku nowych produktów, procesów lub sposobów postępowania" (za: Jasiński 1992). Z literatury polskiej warto przytoczyć ogólną definicję innowacji jaką zaproponował Z. Pietrasiński, według którego „innowacje są to zmiany celowo wprowadzone przez człowieka lub zaprojektowane przezeń układy cybernetyczne, które polegają na zastępowaniu dotychczasowych stanów rzeczy innymi, ocenianymi dodatnio w świetle określonych kryteriów i składającymi się w sumie na postęp" (za: Jasiński 1992). Tak więc możemy powiedzieć, iż innowacje są następstwem postępu naukowo-technicznego, są ściśle związane z przedsiębiorczością, a ich wdrażanie jest związane ze szczególnie wysokim stopniem ryzyka, dlatego też w wysoko rozwiniętych gospodarkach rynkowych wykształcono specjalne sposoby ich finansowania.

Z punktu widzenia marketingu i marketingu przemysłowego innowacja to zastosowanie nowych pomysłów, rodzajów polityki rynkowej, sposobów dystrybucji i promocji, technologii, wejście na nowe rynki, wypuszczenie nowego produktu lub jakakolwiek świadoma, istotna zmiana elementu marketingu stosowanego przez firmę. Innowacje produktowe odgrywają bardzo ważną rolę w strategii marketingowej przedsiębiorstw, produkujących zarówno dobra jak i usługi. W cyklu życia każdego produktu wytwarzanego przez przedsiębiorstwo następuje faza schyłkowa, dlatego też innowacje są podstawowym warunkiem długookresowego rozwoju przedsiębiorstwa. Zaakceptowane przez rynek innowacje produktowe dają przedsiębiorstwu przewagę nad konkurentami, a w niektórych przypadkach mogą stworzyć szansę na uzyskanie okresowej pozycji monopolistycznej. W dobie globalizacji oraz postępującej w sposób ciągły integracji krajów Europy konkurencyjność przedsiębiorstw w skali mikroekonomicznej jest uwarunkowana stopniem zaawansowania technologicznego i konkurencyjnością całego kraju (Markowska, Müller). W środowisku rynkowym możemy wyróżnić pewną grupę konsumentów, którzy są skłonni jako pierwsi nabywać i wypróbowywać nowo wprowadzone na rynek dobra i usługi. Grupę tę nazwano ,innowatorami” (Wiśniewski 1993). Teorię innowacji do nauk ekonomicznych wprowadził J. Schumpeter, który po raz pierwszy w teorii ekonomii sformułował pięć przypadków pojawienia się nowych kombinacji elementów przyrodniczych i produkcyjnej siły człowieka. Schumpeter stwierdza, że innowacje to nowe kombinacje zachodzące w następujących przypadkach (Pomykalski 2001): 
- wytworzenie nowego produktu lub wprowadzenie na rynek towarów o nowych właściwościach,

- wprowadzenie nowej metody produkcji,

- otwarcie nowego rynku zbytu,

- zdobycie nowych źródeł surowców,

- przeprowadzenie nowej organizacji jakiegoś przemysłu.

Według Pomykalskiego innowacja pojmowana jest jako proces obejmujący wszystkie działania związane z kreowaniem pomysłu, powstaniem wynalazku, a następnie wdrażaniem nowego lub ulepszonego produktu, procesu czy też usługi (ryc. 1).

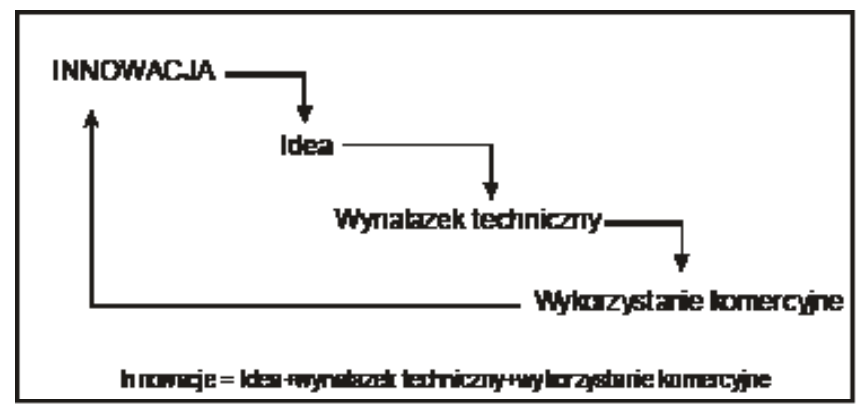

Ryc. 1. Innowacja jako proces

Źródło: Opracowanie własne na podstawie Pomykalski 2001

Punktem wyjścia dla innowacji jest koncepcja teoretyczna, idea. Jednak sam pomysł nie jest innowacją i nie jest też wynalazkiem. Pozostaje on jedynie pewną ideą, która jest początkiem procesu innowacji. Innowacje są rezultatem procesów technicznych, społecznych, ekonomicznych, prawnych, kulturowych i organizacyjnych, które można kształtować. Obecnie pod pojęciem innowacji rozumie się pewien kompleks procesów i zjawisk obejmujących nie tylko powstawanie i wdrażanie innowacji, ale także jej efektywność ekonomiczno-społeczną. Peter Drucker (1992) uważa, że innowacje to specyficzne narzędzie w ręku przedsiębiorcy, które ze zmiany czyni okazję do świadczenia nowych usług lub podjęcia nowej działalności gospodarczej. Postrzega on innowacje bardziej jako pojęcie ekonomiczne lub społeczne niż o charakterze technicznym, które oznacza zmianę wartości i zaspokojenia konsumenta przez wykorzystanie określonych zasobów. Ch. Freeman uważa, że innowacja ma miejsce dopiero po pierwszym handlowym wprowadzeniu nowego produktu lub zastosowaniu danego procesu, urządzenia lub systemu (Jasiński 1992). Powszechnie wiadomo, że duża liczba praktyków i teoretyków nauk ekonomicznych nie przypisuje pojęcia innowacji do pierwszych zastosowań urządzenia, produktu czy systemu. J. Pajestka podziela ten pogląd i twierdzi, iż „nie ma znaczenia, że produkty czy technologie (jako metody wytwarzania) znane są gdzie indziej; dla danego społeczeństwa, które ich wcześniej nie znało, są one bez wątpienia innowacjami [...] dla analizy procesów rozwojowych bardziej słuszne jest takie rozumienie pojęcia «innowacje», w którym innowacją jest nie tylko to, co jest absolutną nowością w skali światowej, ale to co jest nowością dla danego społeczeństwa" (za: Jasiński 1992). Nieco inaczej do pojęcia innowacji podchodzi G.S. Altshuller, który szczególnie podkreśla 
związek innowacji z kreatywnością. Uważa on, że kreatywność to zjawisko złożone, zbiór pewnych umiejętności pozwalających na inne postrzeganie świata, tworzenie nowych idei, umiejętność syntezy i wyrażania wiedzy, odmienne sposoby organizowania. Innymi słowy, są to pewne procesy twórcze możliwe do nauczenia i systematycznego wprowadzania. G.S. Altshuller uważa, że innowacyjność to zdolność przekształcenia kreatywności w rzeczywistość, czego wynikiem jest innowacja.

Według Stefana Marciniaka (1997) innowacja to twórcze zmiany w systemie społecznym, w strukturze gospodarczej, w technice oraz w przyrodzie. Tak więc w najbardziej ogólnym podziale innowacji wyróżnia się następujące jej rodzaje:

- innowacje antropocentryczne - dotyczące różnych przejawów życia jednostek ludzkich,

- innowacje społeczne - dotyczące organizacji stosunków międzyludzkich,

- innowacje biotyczne - innowacje w zakresie przyrody,

- innowacje techniczne - dotyczące zmian w technice i technologii.

Innowacje techniczne można podzielić na dwie następujące grupy: innowacje produktowe oraz innowacje procesowe. Z punktu widzenia marketingu innowacje produktowe stanowią bardzo ważny element całej strategii marketingowej przedsiębiorstwa, a czasem mogą decydować o istnieniu przedsiębiorstwa na rynku.

Innowacje produktowe to wszelkie zmiany polegające na udoskonaleniu wyrobu już wytwarzanego przez przedsiębiorstwo, bądź na rozszerzeniu struktury asortymentowej o nowy produkt. Produkt nowy pod względem technologicznym to produkt, którego cechy technologiczne lub przeznaczenie różnią się znacząco od uprzednio wytwarzanych. Innowacje tego typu mogą wiązać się z całkowicie nowymi technologiami, opierać się na połączeniu istniejących technologii w nowych zastosowaniach lub też na wykorzystaniu nowej wiedzy. Innowacja produktowa została wdrożona, jeśli została wprowadzona na rynek. Stosowany tu termin produkt należy rozumieć w ujęciu marketingowym, obejmującym zarówno towary, jak i usługi.

Przykładem innowacji produktowej jest wprowadzenie nowego modelu samochodu lub nowej usługi. Współczesna forma konkurencji opiera się nie tylko na konkurencji cenowej, lecz także na konkurencji produktowej. Dlatego też innowacje produktowe mają tak wielkie znaczenie w obecnej gospodarce rynkowej. Innowacje produktowe powodują uruchomienie procesów innowacyjnych w tych gałęziach, które są odbiorcami nowego produktu. Tak więc innowacje produktowe oddziaływują na inne dziedziny, a określenie „,nowy produkt” nie jest jednoznaczne i zależy od punktu odniesienia. W zależności od stopnia innowacji wyróżnia się kilka kategorii nowego produktu dla rynku czy dla przedsiębiorstwa (Pomykalski 2001).

- nowy produkt na nowym rynku (10\% wszystkich innowacji produktu);

- nowy produkt na istniejącym rynku: uzupełniający linię oferowaną na rynku, nowy dla firmy, „stary” dla klientów (80\% udziału w innowacji produktu);

- ulepszenie istniejącego produktu: zastapienie przez produkt sprawniejszy, zastąpienie przez podobny produkt o niższych kosztach ( $10 \%$ udziału w innowacji produktu).

Szczególną rolę w obecnej gospodarce rynkowej odgrywa nowy produkt. Jest on jednym z narzędzi wykorzystywanych w walce konkurencyjnej między przedsiębiorstwami.

W ujęciu marketingowym (Altkorn 1997) innowacje produktowe to:

- produkty całkowicie nowe, zaspokajające potrzeby dotychczas nie zaspokojone,

- produkty lepiej lub gorzej zaspokajające potrzeby zaspokajane dotąd przez inne produkty. 
W skład pierwszej grupy wchodzą produkty, które zaspokajają potrzeby wcześniej znane, ale nie zaspokajane, jak i potrzeby wcześniej nie odczuwane, które zostały rozbudzone u konsumenta poprzez prowadzenie odpowiednich działań marketingowych. Drugą grupę produktów możemy podzielić następująco:

- produkty o nowych rozwiązaniach funkcjonalnych, wynikających z zastosowania nowych technik i technologii produkcji (na przykład przedmioty o znanym przeznaczeniu, ale wyrabiane z nowych surowców),

- produkty o nowych rozwiązaniach estetycznych, osiągniętych dzięki nowym technikom i technologii oraz wkładowi artyzmu (na przykład nowe kształty mebli z mas plastycznych).

Obok produktów nowych wyróżnić można także produkty modernizowane i produkty usprawniane. Celem modernizacji nie jest stworzenie produktu nowego, lecz jedynie poprawienie produktu już istniejącego na rynku. Modernizacje i usprawnienia mogą dotyczyć zarówno samego produktu, jak i elementów jego wyposażenia. Zmiany takie mogą mieć charakter radykalny lub też mało znaczący. Nowość produktu jest definiowana przede wszystkim przez percepcję indywidualnego konsumenta. Dla konsumenta nowy produkt to wyrób lepiej zaspokajający potrzebę dotychczasową. Zdaniem A. Robertson (Pomykalski 2001), z punktu widzenia rynku wyróżnia się trzy rodzaje innowacji:

- innowacje ciagłe,

- innowacje dynamicznie ciagłe,

- innowacje nieciagłe.

Innowacje ciągłe mają niewielki wpływ na wzory konsumpcji. Polegają one na niewielkiej modyfikacji istniejących produktów. Przykładem może być tu dodanie witaminy C do soku. Przy tego rodzaju innowacji nie ma zmiany zachowań konsumentów. Innowacje dynamicznie ciagłe w niewielkim stopniu wymagają zmiany zachowań konsumenta, lecz zmiany te są niezbędne. Innowacje nieciagłe są produktami zupełnie nowymi, a wprowadzenie ich na rynek powiązane jest z nauczeniem konsumenta całkowicie nowych wzorców konsumpcji.

Altkorn (1997) uważa, iż ekonomiczną miarą innowacji jest siła, z jaką oddziałuje ona na rynek. Stwierdza on, że: „,innowacja zorientowana na produkt wytwarza czasami «cuda techniki», ale wpływy z niej są przeważnie znikome”. Dokonał on podziału innowacji produktowych na innowacje absolutne (oryginalne), oznaczające nowości w skali światowej oraz innowacje wtórne, polegające na upowszechnianiu produktów znanych już gdzie indziej, ale nieznanych na rynku krajowym czy lokalnym. Proces rozprzestrzeniania się innowacji nazywamy dyfuzją. Zjawisko jakim jest dyfuzja ma charakter falowy, a pojawienie się innowacji absolutnej daje impuls do rozchodzenia się fali upowszechniania.

Innowacje procesowe (technologiczne) stanowią niejako too dla innowacji produktowych. Sa to zmiany w stosowanych przez organizację metodach wytwarzania, a także w sposobach docierania z produktem do odbiorców. Metody te mogą polegać na dokonywaniu zmian w urządzeniach lub w organizacji produkcji, mogą też stanowić połączenie tych dwóch rodzajów zmian lub być wynikiem wykorzystania nowej wiedzy. Mogą mieć one na celu produkcję lub dostarczenie nowych lub udoskonalonych produktów, które nie mogłyby być wytworzone czy też dostarczone przy pomocy metod konwencjonalnych. Celem tych metod może być także zwiększenie efektywności produkcji lub dostarczenie istniejących produktów.

Zazwyczaj poszczególne rodzaje innowacji są ze sobą połączone, gdyż wiele innowacji produktowych nie mogłoby istnieć bez innowacji procesowych jak i zmian w organizacji 
pracy. Podstawową różnicą między innowacjami procesowymi a produktowymi jest to, że innowacje produktowe są bardziej wrażliwe na czynniki rynkowe. Przykładem innowacji procesowej niewątpliwie może być zmiana metody wytwarzania oraz maszyn wykorzystywanych $\mathrm{w}$ procesie produkcji danego produktu, jak również zmiana procedur biurowych w przypadku usługi.

Dlatego też, stosując marketing nie można zapominać o tak ważnym, bezpośrednio wpływającym na konkurencyjność czynniku jakim są innowacje.

Każdy czynnik wpływający na działalność przedsiębiorstwa musi posiadać swoje źródło. Dotyczy to również innowacji. Źródłem innowacji jest wszystko to, co inspiruje człowieka do procesu zmian. A zatem źródłem innowacji jest środowisko stymulujące procesy zmian, pozwalające człowiekowi w sposób kreatywny reagować na zmieniające się otoczenie. Aby sprostać wymaganiom współczesnej gospodarki rynkowej, nieuniknione jest prowadzenie badań naukowych w zakresie zarządzania, produkcji, dystrybucji, promocji, a także innych dziedzin. Źródłami kreowania zmian (Pomykalski 2001) w tych dziedzinach są przede wszystkim:

- transfer technologii,

- działalność sfery B+R,

- prowadzenie różnego rodzaju badań marketingowych zarówno na rynkach krajowych, jak i zagranicznych,

- wykorzystanie metod gromadzenia pomysłów, takich jak na przykład „burza mózgów",

- doradztwo firm konsultingowych,

- stymulowanie kreatywności pracowników i kierownictwa.

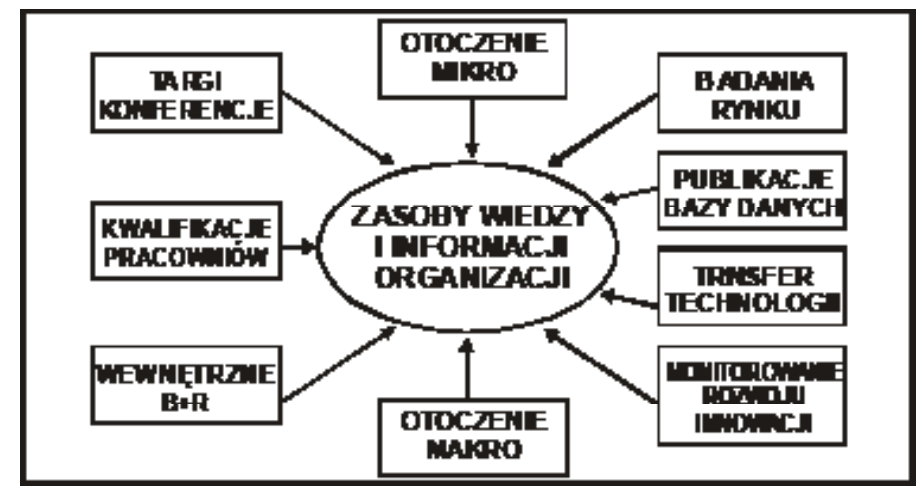

Ryc. 2. Źródła kreowania zasobów wiedzy i informacji organizacji

Źródło: Opracowanie własne na podstawie Pomykalski 2001

Zdaniem Philipa Kotlera, ,pomysły na nowy produkt mogą pochodzić z wielu źródeł: od klientów, naukowców, konkurentów, pracowników, uczestników kanałów dystrybucji i zarządu" (Kotler 1999). Dlatego też nowocześnie zarządzana organizacja powinna szczególną uwagę zwracać na pochodzące z różnych źródeł zasoby wiedzy i informacji. 


\section{EWOLUCJA I ROZWÓJ INNOWACJI}

Po drugiej wojnie światowej w praktyce zarządzania przedsiębiorstw dominował tak zwany liniowy model innowacji. Jest on logiczny i wyraźnie przedstawia funkcje poszczególnych podmiotów uczestniczących w procesach innowacji. Wczesne modele procesu innowacji kładły nacisk na przyczynową rolę osiągnięć naukowo-technicznych. Tego typu model określany jest jako model innowacji ,pchanej” przez naukę (ryc. 3a). Zakłada on, iż osiagnięcia sfery badań podstawowych prowadzą do rozwoju techniki przemysłowej, która powoduje wpływ nowych produktów i procesów technologicznych na rynek. W modelu tym użytkownikowi przypisuje się mniej lub bardziej pasywną rolę, a rynek jest niejako „odbieralnikiem" rezultatów naukowo-technicznego wysiłku przedsiębiorstwa. Tak więc polityka przedsiębiorstwa bazująca na takim modelu kładzie nacisk na czynniki podażowe, ignorując jednocześnie czynniki popytowe (Jasiński 1992). Rola jaką w procesie innowacyjnym odgrywają odczuwane potrzeby rynkowe zaczęła być akcentowana dopiero od połowy lat sześćdziesiątych. Stwierdzono bowiem, że 75\% udanych innowacji pojawiło się jako reakcja na rozpoznanie potrzeby rynkowej. Zostało to ujęte jako liniowy model innowacji „ciagnionej” przez rynek (ryc. 3b). W modelu tym innowacje techniczne powstają jako rezultat dostrzeżonych i przejrzyście wyartykułowanych potrzeb społecznych. Przedsiębiorstwa stosujące tego typu politykę muszą liczyć się z ryzykiem popadnięcia w sferę niewielkich, przyrostowych innowacji w już istniejących obszarach (Jasiński 1992).

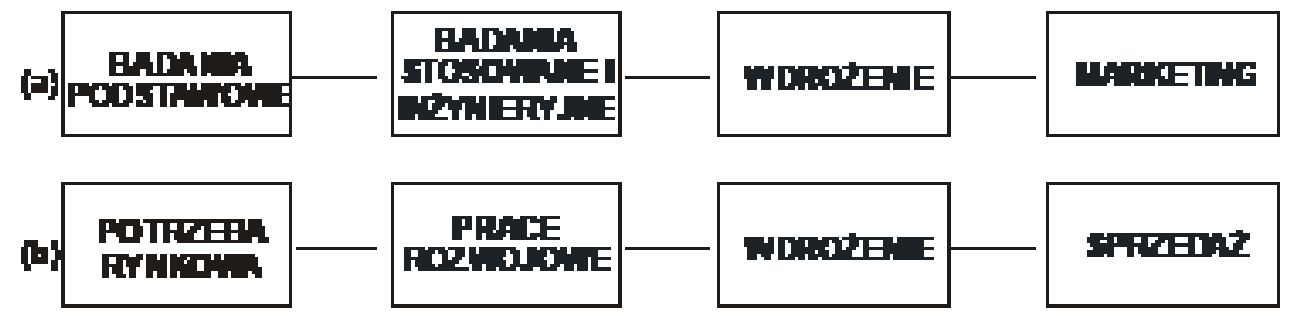

Ryc. 3. Model innowacji (a) „pchanej” przez naukę, (b) „,ciagnionej” przez rynek

Źródło: Jasiński 1992

Pod koniec lat siedemdziesiątych modele innowacji ,pchanej” przez naukę i innowacji „ciagnionej” przez rynek były traktowane jako skrajne i nietypowe przykłady ogólnego procesu sprzęgania się nauki, techniki i rynku. Powstał więc model sprzężeniowy procesu innowacyjnego. Innowacja pojmowana jest tu jako logicznie sekwencyjny, niekoniecznie ciagły proces, który można podzielić na ciąg funkcjonalnie odrębnych, lecz sprzężonych i współzależnych faz (Jasiński 1992). Tak postrzegany proces w ramach przedsiębiorstwa innowacyjnego reprezentuje połączenie możliwości technicznych z potrzebami rynkowymi. W modelu tym (ryc. 4) istotnym czynnikiem jest to, iż przedsiębiorstwo w jak najwcześniejszym etapie procesu innowacyjnego sprzęga możliwość technologiczną z potrzebami rynku. 


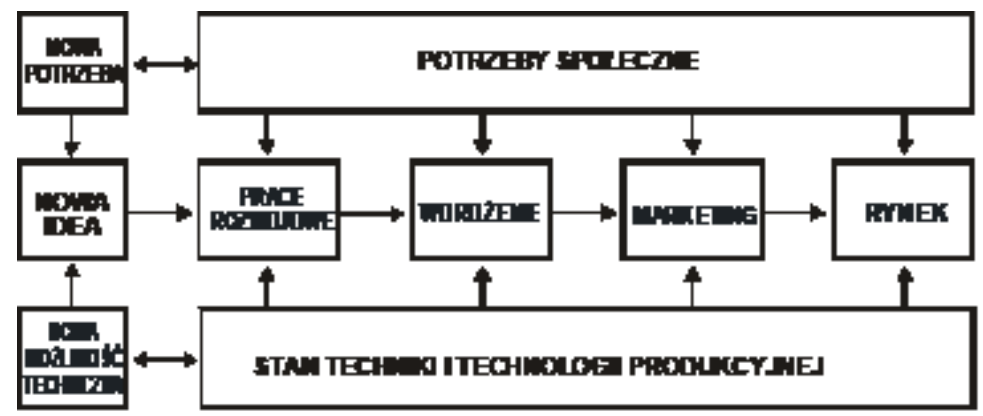

Ryc. 4. Model sprzężeniowy procesu innowacyjnego

Źródło: Jasiński 1992

W sposobie postrzegania procesu innowacyjnego nastapiło wiele zmian. R. Rothwell stwierdza istnienie „modelu innowacji piątej generacji”, który zakłada istnienie wieloczynnikowego procesu wymagającego wysokiego poziomu integracji czynników zarówno wewnętrznych jak i zewnętrznych, wspomaganych przez sieci komputerowe (tab. 1).

Tabela 1. Pięć generacji modeli innowacji R. Rothwella

\begin{tabular}{|l|l|}
\hline \multicolumn{1}{|c|}{ Generacja } & \multicolumn{1}{c|}{ Podstawowe cechy } \\
\hline Pierwsza / druga & Model liniowy - model podażowy, model popytowy. \\
\hline Trzecia & $\begin{array}{l}\text { Model powiązany, zakładający interakcję różnych elementów oraz } \\
\text { sprzęzenia zwrotne informacji. }\end{array}$ \\
\hline Czwarta & $\begin{array}{l}\text { Model równoległy, integracja wewnętrzna firmy oraz współpraca z do- } \\
\text { stawcami i odbiorcami, akcent kładziony na powiązania i alianse. }\end{array}$ \\
\hline Piąta & $\begin{array}{l}\text { System zintegrowany oparty na sieciowych powiązaniach: elastyczny, } \\
\text { oparty na systemie odpowiedzi powiązanej z konsumentem, innowacja } \\
\text { ciagła. }\end{array}$ \\
\hline
\end{tabular}

Źródło: Pomykalski 2001

Zapotrzebowanie na innowacje inspirowane jest okolicznościami rynkowymi. Zespół tych okoliczności stanowi jednocześnie źródło sygnałów informujących o rozmiarach i strukturze owego zapotrzebowania. Pomykalski (2001) stwierdza, iż podaż innowacji uzależniona jest przede wszystkim od dwóch następujących czynników wzajemnie na siebie oddziaływujących:

- mechanizmu funkcjonowania gospodarki i związanych z nim procesów zarządzania, które stymulują rozwój innowacji,

- możliwości finansowo-rzeczowych organizacji w zakresie finansowania rozwoju oraz lokowania nadwyżek finansowych.

Celem każdej organizacji powinno być aktywne dążenie do kierowania procesem innowacji (ryc. 5). Griffin przedstawiając etapy procesu innowacji stwierdza, że jednoczesne sprzedanie klientowi nowych produktów i usług wymaga, aby organizacja dysponowała odpowiednimi zasobami. 


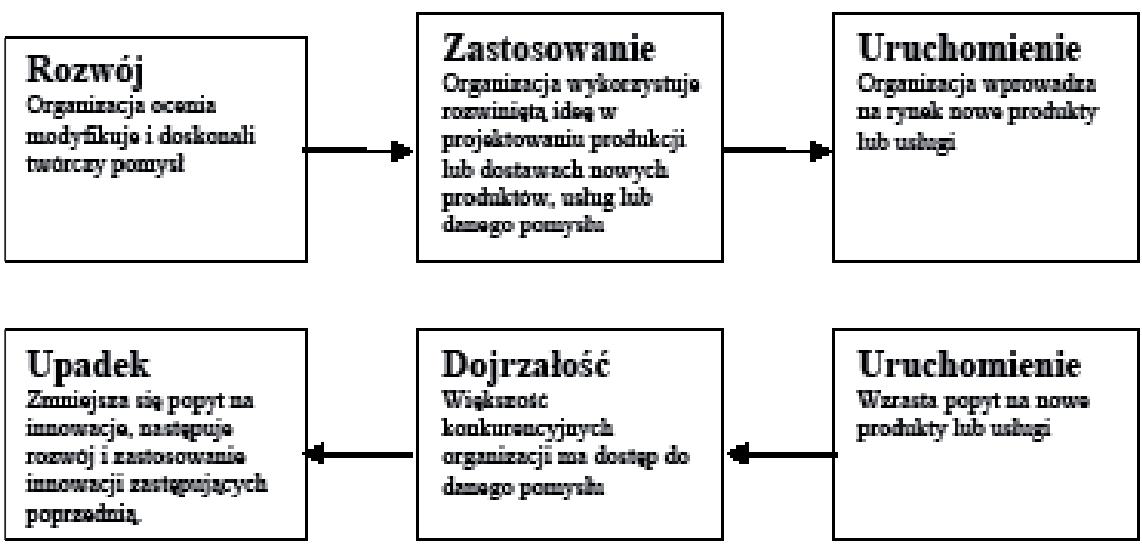

Ryc. 5. Organizacyjny proces innowacji

Źródło: Pomykalski 2001

Nowoczesne ujęcie procesu innowacyjnego określane jest dynamicznym interakcyjnym modelem innowacji, definiowanym jako ciag interakcji od powstania idei innowacji do jej komercjalizacji rozumianej tu jako wdrożenie i dyfuzję. W procesie tym możemy mówić o stymulującym sukces rynkowy nowym rodzaju organizacji produkcji, sfery badań i rozwoju oraz marketingu. Taki interakcyjny model innowacji, który obejmuje zarówno wewnętrzne jak i zewnętrzne powiązania, może być rozważany jako stały zbiór połączeń informacyjnych, którymi jest transferowana wiedza (Pomykalski 2001). W tym modelu innowacji nacisk kładziony jest na projektowanie inżynierskie, sprzężenia zwrotne pomiędzy rynkowymi i technologicznymi fazami innowacji, powiązania pomiędzy sferą badań i rozwoju, produkcją i marketingiem, a także powiązania między firmami i instytucjami. W modelu tym dużą wagę mają interakcje pomiędzy funkcjami wewnątrz organizacji, jak i interakcje tych funkcji z zewnętrznym otoczeniem.

Dział marketingu powinien komunikować się z otoczeniem zewnętrznym przedsiębiorstwa w celu uzyskania pewności, że podczas realizacji celów przedsiębiorstwa firma coraz lepiej dostrzega potrzeby konsumenta i dostarczane na rynek produkty znajdą nabywców. W kontaktach zewnętrznych marketingu możemy wymienić przede wszystkim takie jednostki, jak dostawcy, dystrybutorzy, konsumenci, a także konkurencja. Wszystkie te informacje odbierane z zewnętrznego otoczenia przedsiębiorstwa wzbogacają wiedzę przez nie gromadzoną. Istotne jest znaczenie zarówno formalnych, jak i nieformalnych interakcji. Jak widać na schemacie, w centrum interakcyjnego modelu innowacji znajdują się funkcje organizacyjne, takie jak: sfera badań i rozwoju, produkcja oraz marketing. Model ten sprawia wrażenie liniowego, jednak przepływ informacji nie jest liniowy i występują tu również powiązania zwrotne. Można powiedzieć, że funkcjonowanie interakcyjnego modelu innowacji zależy głównie od dwóch następujących czynników: zasobów organizacji, na które składają się osiagnięcia naukowe i techniczne, oraz potrzeb społecznych i rynkowych (Pomykalski 2001). W tym modelu B. Twiss ukazuje nam serię działań w obrębie wewnętrznego otoczenia przedsiębiorstwa - od kreatywności aż do nowego produktu (ryc. 6). 


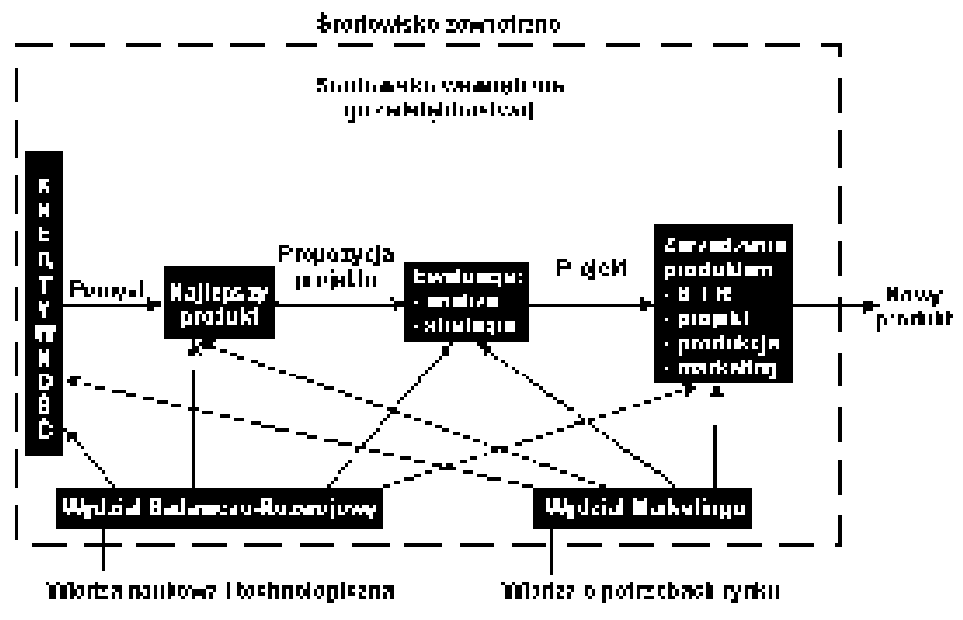

Ryc. 6. Model B. Twissa

Źródło: Pomykalski 2001

W modelu tym wpływ czynników zewnętrznych, takich jak wiedza naukowa i potrzeby rynku następuje poprzez konkretne wydziały przedsiębiorstwa: wydział badawczo-rozwojowy oraz wydział marketingu. Można łatwo zauważyć przepływ działań zachodzących w procesie innowacji oraz formę jaką przybiera innowacja w kolejnych fazach procesu. Innowacja jest tu więc pojmowana jako seria typów działań. Takie spojrzenie na innowację przyczynia się zazwyczaj do dokładniejszego przedstawienia procesu. Podejście to nie jest jednak doskonałe, gdyż pokazuje prosty postęp od fazy do fazy, nie dając wskazówek alternatywnych ścieżek możliwych w poszczególnych punktach procesu. Zasadniczym problemem w projektowaniu interakcyjnego modelu innowacji jest dostrzeżenie w konkurencyjnej gospodarce nowej szansy rynkowej dla wdrażanego nowego produktu. Następne fazy to formułowanie koncepcji produktu, procedury i operacje niezbędne dla rozwoju nowych innowacji. Zasadniczą rolę $\mathrm{w}$ procesie innowacji odgrywa projektowanie, które prowadzi do budowy i testowania prototypów, jak i do oceny rynkowej. W całym procesie innowacji najważniejszym, a zarazem najtrudniejszym etapem jest wdrażanie innowacji. Z braku koordynacji i integracji przedsięwzięcia badawczego z wszystkimi elementami procesu produkcyjnego i rynkowego etap ten często kończy się niepowodzeniem (Pomykalski 2001). Według Druckera (1995), ,pierwszym warunkiem wprowadzenia innowacji jest postrzeganie zmiany jako potencjalnej szansy, nie zaś zagrożenia”. Proces innowacji może być na bieżąco regulowany poprzez szybkie wprowadzanie zmian, jednakże istotne jest, ażeby innowacja wyróżniała się następującymi cechami:

- dużą elastycznością,

- wielowariantowością,

- realnością techniczną, technologiczną i organizacyjną.

Najważniejsze jednak jest, by przy wdrażaniu innowacji stosować podejście systemowe uwzględniając w procesie innowacji podsystemy organizacji, takie jak: 
- materialno-techniczny (posiadanie odpowiedniej aparatury i urządzeń),

- ludzki (wiedza, kreatywność, motywacja, sposoby zachowania),

- organizacyjno-informacyjny,

- ekonomiczno-finansowy.

W celu prawidłowego przebiegu procesu wdrażania innowacji, wszystkie wyżej wymienione podsystemy muszą dostosować się do zmiany zainicjowanej w jednym z nich. Jeżeli takie przystosowanie nie nastąpi, innowacja nie przyniesie spodziewanych pozytywnych efektów, a wręcz przeciwnie, może doprowadzić do nieprawidłowości w funkcjonowaniu organizacji (Pomykalski 2001).

\section{PRZEDSIĘBIORSTWO INNOWACYJNE}

Według L. Zbiegień-Maciąg i W. Pawnika jedną z dominujących cech współczesnych społeczeństw jest obecność i siła oddziaływania organizacji. Organizacje, zarówno duże, jak i małe obejmują swym zasięgiem szerokie pole aktywności, nas wszystkich (ZbiegieńMaciagg, Pawnik 1998). Z punktu widzenia organizacji jej otoczenie reprezentuje zbiór zmiennych niezależnych. Zmienne te to czynniki, które znajdują się w przeważającym zakresie poza jej kontrolą. Większość z tych czynników zachowuje taki charakter pomimo licznych prób kształtowania otoczenia przez organizację. Przez otoczenie rozumie się zbiór składników, takich jak pieniądze, materiały, ludzie, energia, informacje, których nie zalicza się do składników samej organizacji, ale ich bezpośrednie oddziaływanie lub zmiana właściwości może spowodować zmianę stanu samej organizacji. Tak więc otoczenie jest środowiskiem, w którym organizacja funkcjonuje (Pomykalski 2001).

Zachowanie się organizacji kształtowane jest przez otoczenie. Otoczenie to można podzielić na otoczenie bliższe, zwane mikrootoczeniem, oraz otoczenie dalsze, zwane makrootoczeniem. W rzeczywistych systemach odpowiednie zachowanie się organizacji polega na reagowaniu na zmiany zachodzące $w$ otoczeniu, a także $w$ samej organizacji po to, aby zapobiec zmniejszeniu efektywności działania systemu. Żadna zmiana nie wynika tylko z jednej przyczyny. Motywy zmian zawsze są kombinacją wielu czynników zarówno zewnętrznych jak i wewnętrznych, o relatywnie zmiennym otoczeniu. W niektórych przypadkach możemy zauważyć silną dominację jednej przyczyny, jak np. konkurencja czy technologia, podczas gdy w innych przypadkach występuje wiele różnych przyczyn.

Skala innowacji jest ściśle związana z poziomem inwestycji przemysłowych oraz tempem wzrostu ekonomicznego. W przypadku gdy gospodarka charakteryzuje się małym stopniem inwestycji przemysłowych i niskim wzrostem ekonomicznym nie można liczyć na osiagnięcie rozwoju w zakresie innowacji. Dlatego też przedsiębiorstwa innowacyjne powinny poświęcać dużo uwagi badaniom otoczenia, w którym funkcjonują. Na potrzeby badawcze niezbędne jest dokonanie klasyfikacji elementów otoczenia. Podziału otoczenia organizacji można dokonać z punktu widzenia czynników, które to otoczenie kształtują oraz z punktu widzenia jednostek organizacyjnych (Jasiński 1992). 
Tabela 2. Podział otoczenia organizacji

\begin{tabular}{|l|l|}
\hline $\begin{array}{c}\text { Podział z punktu widzenia } \\
\text { czynników je ksztaltujących }\end{array}$ & \multicolumn{1}{|c|}{$\begin{array}{c}\text { Podzial z punktu widzenia } \\
\text { jednostek organizacyjnych }\end{array}$} \\
\hline demograficzne & gospodarstwa domowe \\
\hline ekonomiczne & banki \\
\hline polityczno-prawne & organy administracji państwowej, sądy \\
\hline techniczne & placówki badawczo-rozwojowe \\
\hline kulturowe & organizacje polityczne i społeczne \\
\hline naturalne & przedsiębiorstwa \\
\hline
\end{tabular}

Źródło: Pomykalski 2001

Takiego rodzaju podziału można dokonać zarówno biorąc pod uwagę otoczenie krajowe, jak i zagraniczne. Warto też zauważyć, iż oba wyżej wymienione podziały niejednokrotnie się zazębiają. W obecnych czasach warunki funkcjonowania przedsiębiorstw podlegają ciągłym zmianom, dlatego też szczególnie ważne staje się reagowanie na zachodzące zmiany. Działające na przedsiębiorstwo zmiany w ich otoczeniu zewnętrznym oraz zmiany wewnątrz organizacji powodują, iż niezmiernie ważne w ich działalności staje się skuteczne zarządzanie zmianami. Firmy innowacyjne muszą skutecznie rozpoznawać charakter i przyczyny przemian, co pozwoli na efektywne zarządzanie zmianami oraz przedsięwzięciami z nimi związanymi (Zys 2003). Przedsiębiorstwo innowacyjne reaguje na zmiany w swym otoczeniu skutecznie wprowadzając innowacje, co pozwala im na osiagnięcie wielu znaczących efektów, które często przesądzają o istnieniu organizacji. Przedsiębiorstwa te poprzez innowacje polepszają i unowocześniają procesy wytwórcze, podnoszą produktywność, wydajność, a także jakość pracy. Przedsiębiorstwo innowacyjne, podnosząc jakość swoich wyrobów, zwiększając ogólną sprawność i efektywność swojego działania poprzez usprawnianie organizacji i metod pracy staje się bardziej konkurencyjne na rynku. Przedsiębiorstwo uważa się za innowacyjne wtedy, gdy tworzy i absorbuje nowe produkty i usługi oraz posiada zdolność ciaggłego adaptowania się do zmian zachodzących w otoczeniu (Zys 2003). Otoczenie organizacji obejmuje wszystkie te czynniki, które oddziaływają na możliwości rozwoju firmy, doprowadzają do zawarcia transakcji oraz budowy współzależności z docelowymi nabywcami (ryc. 7).

Jednostka gospodarcza działająca efektywnie charakteryzuje się przede wszystkim przedsiębiorczością, co związane jest z koniecznością wprowadzania zmian w działalności przedsiębiorstwa. Tak więc jednostka przedsiębiorcza musi być nastawiona na innowacje techniczne i organizacyjne. Można więc zdefiniować przedsiębiorstwo innowacyjne lub inaczej mówiąc przedsiębiorstwo zorientowane na innowacje jako takie, które (Jasiński 1992):

- prowadzi w szerokim zakresie prace badawczo-rozwojowe lub dokonuje zakupów nowych produktów czy technologii,

- przeznacza na tę działalność stosunkowo wysokie nakłady finansowe,

- systematycznie wdraża nowe rozwiązania naukowo-techniczne,

- reprezentuje duży udział nowości (wyrobów i technologii) w wolumenie produkcji i usług,

- stale wprowadza innowacje na rynek.

Przedsiębiorstwa, dla których innowacje stanowią przedmiot podstawowej działalności prowadzącej do wzmocnienia pozycji konkurencyjnej i wzrostu poziomu nowoczesności są 
przedsiębiorstwami innowacyjnymi. Przedsiębiorstwa te charakteryzują się wysoką zdolnością do tworzenia i wdrażania innowacji. Przedsiębiorstwo innowacyjne dba o wysoki poziom kreatywności oraz o przywództwo technologiczne. Współczesne przedsiębiorstwo innowacyjne za podstawowy cel powinno mieć generowanie i tworzenie innowacji, w konfrontacji $\mathrm{z}$ wnikliwym rozpoznaniem potrzeb klienta.

\begin{tabular}{|c|c|c|c|c|c|c|}
\hline \multirow{4}{*}{$\begin{array}{l}\text { Otoczenie } \\
\text { rynkowe }\end{array}$} & \multicolumn{5}{|c|}{ Makrootoczenie } & \multirow{4}{*}{$\begin{array}{c}\text { Otoczenie } \\
\text { konkurencyjne }\end{array}$} \\
\hline & \multicolumn{5}{|c|}{ Mikrootoczenie } & \\
\hline & Konkurencja & & & & Konsumenci & \\
\hline & & & soby fir & & & \\
\hline \multirow[t]{2}{*}{$\begin{array}{l}\text { Otoczenie } \\
\text { ekologiczne }\end{array}$} & \multirow[b]{2}{*}{ Dostawcy } & Produkcyjne & $\mathbf{B}+\mathbf{R}$ & Finansowe & \multirow{3}{*}{ Pośrednicy } & \multirow[t]{3}{*}{$\begin{array}{l}\text { Otoczenie } \\
\text { polityczno- } \\
\text {-prawne }\end{array}$} \\
\hline & & Ludzkie & & Marketingowe & & \\
\hline $\begin{array}{c}\text { Otoczenie } \\
\text { demograficzne }\end{array}$ & \multicolumn{4}{|c|}{ Społeczności } & & \\
\hline $\begin{array}{l}\text { Otoczenie } \\
\text { technologiczne }\end{array}$ & & & & & & $\begin{array}{l}\text { Otoczenie } \\
\text { społeczno- } \\
\text {-kulturowe }\end{array}$ \\
\hline
\end{tabular}

Ryc. 7. Otoczenie i zasoby organizacji a sektor $\mathrm{B}+\mathrm{R}$

Źródło: Pomykalski 2001

Przedsiębiorstwo innowacyjne to inteligentna organizacja, która ustawicznie generuje i realizuje wszelkie przejawy innowacyjności, reaguje dynamicznie na radykalne zmiany otoczenia, a dzięki tym działaniom znajduje uznanie u odbiorców ze względu na wysoki poziom nowoczesności i konkurencyjności (Zys 2003).

Mikrootoczenie obejmuje bardziej specyficzne czynniki związane bezpośrednio lub pośrednio z danym przedsiębiorstwem. W mikrootoczeniu przedsiębiorstw działają dostawcy, pośrednicy, nabywcy, konkurenci, grupy interesu oraz różne społeczności. Dla identyfikacji i analizy tego rodzaju otoczenia zwykle przyjmuje się model „struktury branży” Portera. Autor tego modelu stwierdza (Porter 1992), że stan konkurencji zależy od pięciu podstawowych sił konkurencyjnych, a połączona moc tych sił wyznacza potencjał zysku sektora. Poszczególne sektory różnią się od siebie pod względem ostatecznego potencjału zysku, podobnie jak różni się moc sił. Tak więc, zdaniem Portera, mikrootoczenie organizacji składa się z następujących elementów:

- dostawcy

- odbiorcy/nabywcy

- bariery wejścia na rynek i wyjścia z niego

- substytuty

- konkurenci istniejący i potencjalni.

Między elementami mikrootoczenia organizacji zachodzi sprzężenie zwrotne (ryc. 8). Tak jak podmioty otoczenia oddziałują na przedsiębiorstwo, tak również przedsiębiorstwo 
może reagować na bodźce z otoczenia. Dlatego też przedsiębiorstwa innowacyjne powinny w sposób ciagły rozpoznawać uwarunkowania rynkowe danej branży stosując odpowiednie analizy branżowe, za pomocą których przedsiębiorstwo będzie w stanie gromadzić istotne informacje na temat atrakcyjności rynkowej wprowadzanych innowacji (Pomykalski 2001).

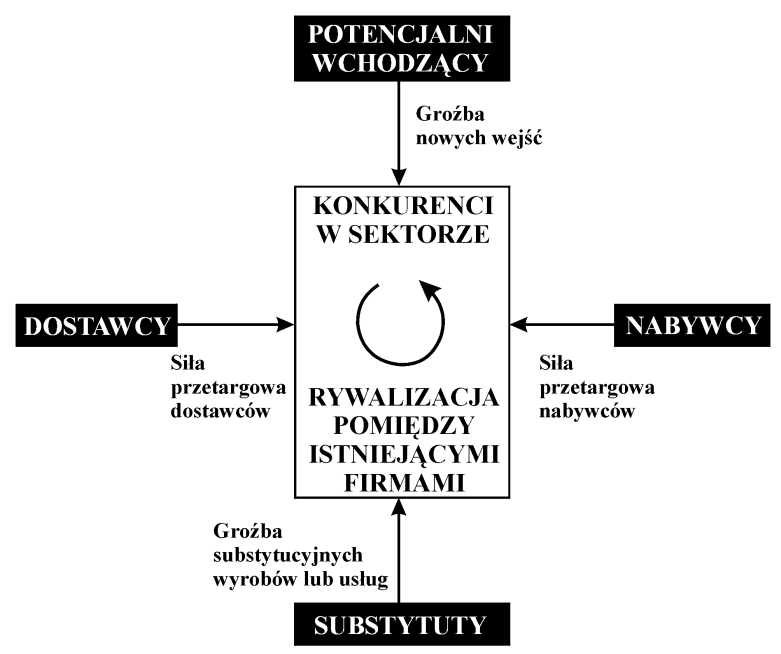

Ryc. 8. Siły napędowe konkurencji wewnątrz sektora

\section{Źródło: Porter 1992}

Sukces przedsiębiorstwa innowacyjnego na rynku oraz realizacja rozwojowych celów zależą od procesu tworzenia i dyfuzji innowacji. Przedsiębiorstwa te borykają się zazwyczaj z podstawowym problemem, jakim jest różnica zdań między poszczególnymi specjalistami co do celów i metod. Wynika to z faktu, że w procesie tworzenia innowacji oraz znalezienia jej optymalnego wykorzystania w produktach bierze udział znaczna ilość specjalistów z różnych dyscyplin naukowych, z różnorodnym zakresem odpowiedzialności (Pomykalski 2001). Współczesne przedsiębiorstwo innowacyjne uzależnione jest od występującego w sposób ciągły oddziaływania otoczenia i rosnących wymagań klientów, przy czym oddziaływanie to jest niezależne od wielkości i przedmiotu działania przedsiębiorstwa. Zdaniem L. Zys (2003), w przedsiębiorstwie innowacyjnym nie powinno stawiać się pytania, czy przeprowadzać zmiany czy też nie, lecz co zmienić i jak szybko? W przedsiębiorstwie innowacyjnym kadra kierownicza powinna przejawiać zrozumienie, że nie istnieje jeden cudowny sposób na sukces w zarządzaniu innowacją. Kadra kierownicza przedsiębiorstwa innowacyjnego powinna pamiętać, że:

- innowacja udaje się w pełni tylko wtedy, gdy jej wprowadzenie wspierane jest przez całą organizację,

- efektywna innowacja oparta jest na strategii, stąd konieczność zintegrowania innowacji z ogólną strategią przedsiębiorstwa,

- powodzenie innowacji zależy od efektywnych powiązań mocnych i słabych stron przedsiębiorstwa $\mathrm{z}$ jego otoczeniem,

- powodzenie innowacji wymaga ze strony organizacji uruchamiania mechanizmów prowadzenia zmian, a w tym budowanie modelu sieciowego opartego na technologii informacyjnej, 
- sukces w zakresie zarządzania innowacjami jest oparty na zdolności organizacji do uczenia się i powtarzania podobnych zachowań (Pomykalski 2001).

Zarządzanie innowacjami w przedsiębiorstwie innowacyjnym powinno być oparte na strukturze modelu sieci uwzględniającej trzy wzajemnie powiązane elementy: podmioty, działania oraz zasoby (ryc. 9).

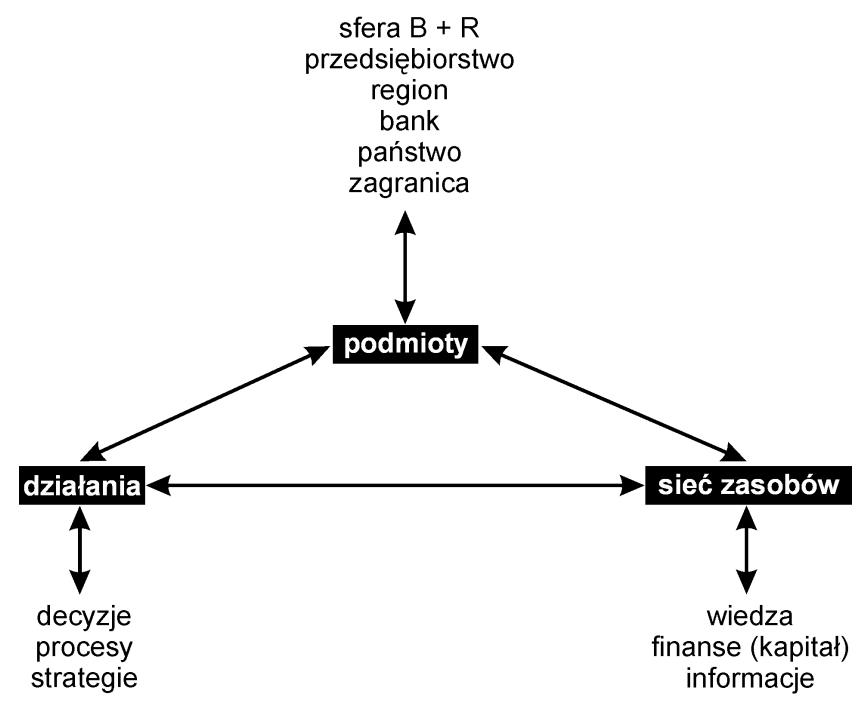

Ryc. 9. Model sieci uwzględniający podmioty, działanie i zasoby

Źródło: Pomykalski 2001

Rozwój wiedzy w przedsiębiorstwie innowacyjnym następuje w miarę jak proces innowacji rozwija się z pierwszej idei poprzez realizację aż do wprowadzenia produktu na rynek. Dlatego też zastosowanie przez przedsiębiorstwo innowacyjne myślenia systemowego w zarządzaniu innowacjami pozwala na (Pomykalski 2001):

- widzenie wielokierunkowych wzajemnych relacji zamiast sekwencji liniowych przyczyna-skutek,

- widzenie procesów zmian w zależności od naszej umiejętności całościowego spojrzenia.

W sposobach wprowadzania zmian w przedsiębiorstwie innowacyjnym w zależności od charakteru realizacji zmian możemy wyodrębnić następujące działania (Zys 2003):

- defensywne - opierające się na określonych produktach, stałych klientach, wąskim obszarze działania, w znacznym stopniu ignorujące zmiany w otoczeniu;

- poszukujące - kiedy następuje poszukiwanie nowych produktów i rozwiązań, monitorowanie zmian, szukanie nowych obszarów działania, nowych technologii;

- analizujące - w ramach których występują działania defensywne oraz poszukujące;

- reagujące - polegające na szybkim powielaniu, adaptacji realizowanych przez innych przedsięwzięć, ale bez wnoszenia własnych rozwiązań.

Myślenie systemowe jest dziś potrzebne bardziej niż pięćdziesiąt lat temu, gdyż w obecnej rzeczywistości jesteśmy przytłoczeni złożonością świata, a zdolność szybszego uczenia 
się może okazać się jedynym trwałym elementem przewagi nad konkurencją. Dlatego też innowacje mogą być głównym czynnikiem stanowiącym o przewadze nad konkurentami. Obecnie, wraz z globalizacją działalności gospodarczej, najlepiej będą sobie radzić, organizacje, które efektywnie będą wykorzystywać zasoby ludzkie. Dobrze prosperujące przedsiębiorstwo innowacyjne to takie, które we wprowadzaniu zmian będzie defensywne i poszukujące. Stwierdzić więc można, że innowacje powinny stanowić integralną część planu marketingowego przedsiębiorstwa, a w związku z tym powinny stanowić jeden z elementów marketingu-mixu przedsiębiorstwa.

\section{Literatura}

Altkorn J., 1997, Podstawy marketingu, Kraków.

Drucker P.F., 1992, Innowacja i przedsiębiorczość. Praktyka i zasady, Warszawa.

Drucker P., 1995, Zarzqdzanie organizacja pozarzqdowq. Teoria i praktyka, Warszawa.

Encyklopedia PWN, 2006, http://encyklopedia.pwn.pl/haslo.php?id=3914833

Jasiński A., 1992, Przedsiębiorstwo innowacyjne na rynku, Warszawa.

Kotler Ph., 1999, Marketing narodów, Kraków.

Marciniak S., 1997, Innowacje i rozwój gospodarczy, Warszawa.

Markowska E., Müller A., Międzynarodowa konkurencyjność gospodarki: Pozycja Polski w przededniu przystapienia do UE, http://www.wsseuczelnia.edu.pl/public/konkurencyjnoscmiedzyn.doc (publikacja elektroniczna).

Nowosad B., 1995, Stownik ekonomiczny i finansowy, Katowice.

Pomykalski A., 2001, Zarzadzanie innowacjami, Warszawa.

Porter M., 1992, Strategia konkurencji, metody analizy sektorów i konkurentów, Warszawa.

Wiśniewski A., 1993, Stownik marketingu, Warszawa.

Zbiegień-Maciąg L., Pawnik W., 1998, Zarzqdzanie organizacja - aspekt socjologiczny, Kraków.

Zys L., 2003, Innowacje, http://imik.wip.pw.edu.pl/innowacje14/strona5.htm

\section{Role of innovation in functioning of industrial enterprises}

Nowadays in Poland many enterprises use instruments of marketing. A part of larger, but especially the smallest enterprises include such operations as promotion for general strategy or advertising. Unfortunately, it does not ensure the achievement of constant, solid competition superiority on the market. From the point of view of marketing as well as industrial marketing, innovation is an implementation of new ideas, a new kind of market policy, new manners of distribution and promotion, entrance on new markets, release of a new product, or conscious, significant change of elements of marketing in the enterprise. Innovations play an important role in creation of the company image on the market. The scale of innovation is strictly related to the level of industrial investment and the economic growth rate. In the case when national economy is characterized by a small degree of industrial investment and low economic growth, considerable development of innovation is not possible. 